\title{
6. MAGNETIC ANISOTROPY OF BARBADOS PRISM SEDIMENTS ${ }^{1}$
}

\author{
Bernard A. Housen²
}

\begin{abstract}
Anisotropy of magnetic susceptibility (AMS) results from sediments spanning the basal décollement of the Barbados accretionary prism show a striking progression across this structure that strongly supports the hypothesis that it is strongly overpressured. In the accretionary prism above the décollement, the minimum AMS axes are subhorizontal and nearly east-west trending, whereas the maximum AMS axes are nearly north-south trending, and shallowly inclined. At the top of the décollement, the AMS minimum axes orientations abruptly change to nearly vertical; this orientation is maintained throughout the décollement and in the underthrust sediments below. The AMS orientations in the prism sediments above the décollement are consistent with lateral shortening caused by regional tectonic stress, as the minimum axes generally parallel the convergence vector of the subducting South American Plate, and the maximum axes are trench-parallel. This abrupt change in AMS orientations at the top of the décollement at Site 948 is a direct manifestation of mechanical decoupling of the off-scraped prism sediments from the underthrust sediments. The decoupling horizon occurs at the top of the décollement zone, coinciding with the location of flowing, high-pressure fluids. Comparison with magnetic fabrics and susceptibilities of the seaward reference site (Site 672) indicates that the AMS fabrics at Sites 948 and 949 record the orientations of neocrystallized (Ti)magnetite and or (Ti)maghemite, and so reflect decoupling of differential stresses (and perhaps also strains) at the top of the décollement. Further comparisons of susceptibility stratigraphy between sediments just above the lithostratigraphic Unit III/Unit II boundary at Sites 672 and 948 suggest that the lower portion of the structurally defined décollement at Site 948 may in fact be largely intact. This suggests that (1) there may be little displacement accommodated by sediments below about $498 \mathrm{mbsf}$; (2) the deformation structures observed in most of the décollement may have formed via low total strains (but perhaps under high strain rates?); and (3) the basal décollement of the Barbados prism is a narrow plane (490-492 mbsf), along which stresses are very effectively decoupled, rather than a thick zone of distributed deformation.
\end{abstract}

\section{INTRODUCTION}

Quantitative studies of mineral fabrics in accretionary prism sediments hold great potential, in that such results can yield data on strain and/or stress orientations and changes in the relative magnitudes of strains, which manifest themselves in the development of mineral preferred orientations. Such studies step beyond the qualitative and semiquantitative description of visual structures and can ultimately provide data that are better suited for constraining the mechanical behavior of deforming sediments. One specific aim of such studies is to evaluate the relative contributions of ductile and brittle components of deformation to the "diffuse strains" (i.e., contributions to bulk shortening caused by small-scale deformation in prism sediments, Karig and Morgan, 1994) observed in prism sediments. The question of whether prism sediments deform primarily by ductile mechanisms, which act to produce a penetrative alignment of mineral orientations, or brittle mechanisms, which are dominated by fractures and result in only very localized zones of mineral alignment, has a great bearing on competing models relating deformation to permeability and porosity variations associated with a prism's basal décollement (Brown et al., 1994).

Direct measurements of strain in accretionary prism sediments are rare because the markers commonly utilized in strain analyses are generally absent (Karig and Lundberg, 1990). Fabric orientations, which may be related to strain geometries, are more readily obtained in accretionary prism sediments by either optical methods (Agar et al., 1989), X-ray texture goniometry (Morgan and Karig, 1993), or mag-

${ }^{1}$ Shipley, T.H., Ogawa, Y., Blum, P., and Bahr, J.M. (Eds.), 1997. Proc, ODP, Sci. Results, 156: College Station, TX (Ocean Drilling Program).

${ }^{2}$ Department of Geology and Geophysics, Institute for Rock Magnetism, University of Minnesota, 293 Shepherd Labs., Minneapolis, MN, 55455-0128, U.S.A. house009@gold.tc.umn.edu netic anisotropy. The last method is particularly suited to the study of fabrics and strains in weakly deformed sediments (Borradaile, 1991), and has been utilized with mixed success in prior studies of the Barbados (Hounslow, 1990), Nankai (Owens, 1993), and Cascadia (Housen and Sato, 1995) accretionary prisms. It should be noted that, while all of these studies identify fabric variations that are related to deformation in these prisms, they all lack comparisons between the fabrics measured in deformed prism sediments and undeformed sediments seaward of the deformation front. Comparisons of this type are particularly important for magnetic fabric studies. The measured anisotropies can be complexly affected by changes in lithology; even subtle variations in oxide or sulfide mineralogy can produce changes in magnetic fabrics that are greater than any changes caused by strain (Borradaile, 1991). A good example of the adverse effect of such variations can be found in the discussion of magnetic fabrics from Site 889 in the Cascadia prism (Housen and Sato, 1995).

An "initial" reference fabric is also required to determine changes in fabrics produced by tectonism, which cannot be known from measurements from sites within the accretionary prism alone. The fabrics measured in sediments from a deformed site will be the end result of an initial (compaction) sedimentary fabric, which is then overprinted by a tectonic fabric. Although some of the effects of tectonism on mineral fabrics can be gathered by comparing fabrics downhole across a structure, absolute variations in fabrics cannot be determined in this way, as downhole variation in lithology, porosity, and degree of compaction may affect the initial (pre-deformation) compaction fabric. The results described in this study are the first to relate changes in fabrics measured in sediments from a seaward reference site (Leg 110, Site 672) to fabrics measured in deformed sediments from the Barbados accretionary prism (Leg 156, Sites 948 and 949). These results expand on an initial study of magnetic fabrics from Site 948 (Housen et al., 1996), which documented decoupling of strains via the agency of high-pressure fluids (Moore et al., 1995) along a narrow horizon at the top of the Barbados décollement. 


\section{STRUCTURES AND SEDIMENTS IN THE BARBADOS PRISM}

Leg 156 of the Ocean Drilling Program (ODP) revisited the area of the Barbados accretionary prism drilled by Deep Sea Drilling Project Leg 78A and ODP Leg 110, with the aim of documenting the relationship between structures and fluid pressure. Site 948 is located about $5 \mathrm{~km}$ west of the deformation front and was cored from 420 to $590 \mathrm{~m}$ below sea floor (mbsf) with good recovery $(>95 \%)$ throughout the drilled interval. The site can be divided into three structural units:

1. the accretionary prism (420-490 mbsf);

2. the décollement zone (490-530 mbsf); and

3. the underthrust sediments (530-590 mbsf; Fig. 1).

The two relevant lithologic units defined for Site 948 are Unit II (420-514 mbsf), a bioturbated claystone with ash layers, and Unit III (514-590 mbsf), a claystone with interbeds of silty clay and nannofossil oozes (Shipley, Ogawa, Blum, et al., 1995). Within the accretionary prism, intervals of scaly fabric are the characteristic macroscopic structures (Shipley, Ogawa, Blum, et al., 1995). Bedding orientations range from nearly horizontal to dips of $60^{\circ}$. The top of the décollement zone is marked by an abrupt increase in the intensity and thickness of the scaly fabric intervals, together with a zone of brecciated sediment and rhodochrosite and phillipsite veins. Indications of focused fluid flow and of high fluid pressures, in the form of geochemical anomalies and abnormally high porosities recorded by core logs (logging-while-drilling), respectively, occur near the top of the décollement zone (Shipley, Ogawa, Blum, et al., 1995; Moore et al., 1995). The lower part of the décollement is characterized by stratal disruption and minor folding. The change in deformation style within the décollement zone is a reflection of the change in lithology at the lithostratigraphic Unit II/Unit III boundary. The underthrust sediments are well bedded, with shallow bedding dips $\left(<30^{\circ}\right)$.

Site 949 is located $2 \mathrm{~km}$ west of the deformation front, and was cored from 244 to $464 \mathrm{mbsf}$ (Fig. 1). Unlike Site 948, sediment recovery was poor at Site 949 , including an interval of no recovery between 312 and 350 mbsf. The poor recovery hampered efforts to de- finitively locate the décollement. The structural units (corresponding to those at Site 948) were identified as follows:

1. the accretionary prism (244-369 mbsf);

2. the décollement zone (399-437 mbsf); and

3. the underthrust sediments (458-464 mbsf).

The structures found in each of these units were similar to those at Site 948, except the structures were either less frequent or were weaker in their expression. Lithostratigraphic Unit II occurs from 244 to $431 \mathrm{mbsf}$, and lithostratigraphic Unit III occurs from 431 to $464 \mathrm{mbsf}$.

Site 672 was drilled during Leg 110 and is located $\sim 5 \mathrm{~km}$ seaward (east) of the deformation front (Fig. 1). Site 672 was cored continuously from 0 to 494 mbsf, with good recovery. Structurally, Site 672 is characterized by horizontal to shallowly-dipping (less than $20^{\circ}$ ) bedding, with some minor faulting and other structures, which may indicate incipient deformation in an interval from 170 to $180 \mathrm{mbsf}$ (Fig. 1). This interval corresponds to the same lithology that occurs at the top of the décollement at Sites 671, 948, and 949, and is referred to as the proto-décollement. Lithostratigraphic units at Site 672 that were sampled for this study are (1) Unit I, a calcareous clay and mudstone with common ash layers (0-123 mbsf); (2) Unit II, lithology as described for Site 948, (123-228 mbsf); and (3) Unit III, lithology as described for Site 948 (228-332 mbsf).

\section{MAGNETIC PROPERTIES OF THE SEDIMENT}

Anisotropy of magnetic susceptibility (AMS) measurements were made on a total of 773 samples $\left(6-\mathrm{cm}^{3}\right.$ volume) from Site 948 (Leg 156, 428 samples, $\sim 1$ sample per $0.5 \mathrm{~m}$ of cored sediment), Site 949 (Leg 156, 165 samples, $\sim 1$ sample per $0.5 \mathrm{~m}$ of cored sediment), and from Site 672 (Leg 110, 180 samples from 0 to 270 mbsf, $\sim 1$ sample per $1.5 \mathrm{~m}$ of cored sediment), using a KLY-2 Kappabridge at the University of Minnesota's Institute for Rock Magnetism. Because all minerals in marine sediments contribute to the low-field magnetic susceptibility measured for AMS, the sources of magnetic susceptibility must be determined to properly evaluate the measured fabrics.

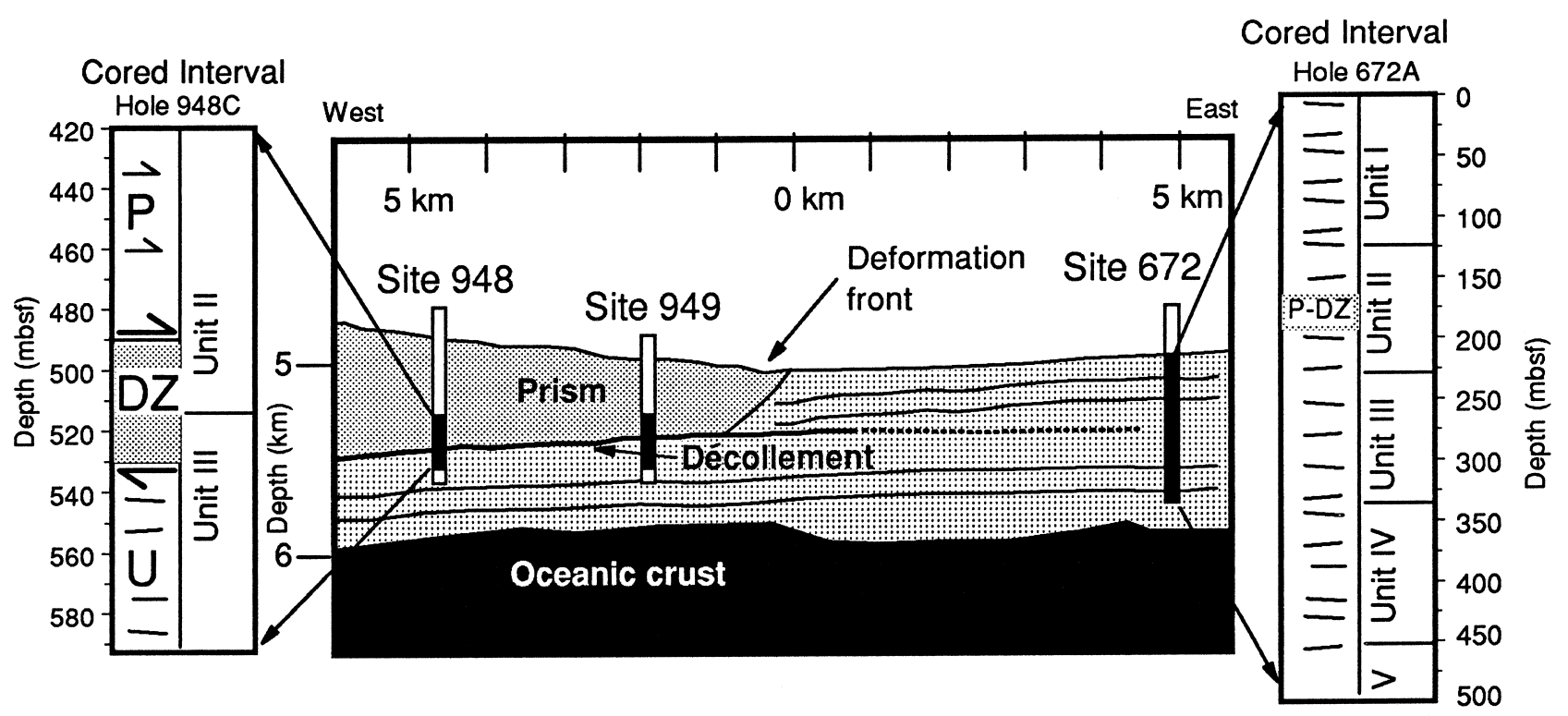

Figure 1. Diagram of Barbados accretionary prism, illustrating major tectonic features and location of ODP Sites 672, 948, and 949. Enlargement at left shows cored interval of Hole $948 \mathrm{C}(420-590 \mathrm{mbsf})$. This interval is subdivided into three structural domains: P is the accretionary prism (420-490 mbsf), DZ is the décollement zone (490-530 mbsf), and $\mathrm{U}$ is the underthrust sediment (>530 mbsf). Half arrows indicate thrust faults. Enlargement at right shows the cored interval of Site 672, with the relevant lithostratigraphic units indicated. The proto-décollement zone identified during Leg 110 is indicated by P-DZ. 
The measured low-field susceptibility can be subdivided into components carried by ferrimagnetic minerals (e.g., magnetite, greigite), paramagnetic minerals (clays and Fe-Mg-Mn minerals), and diamagnetic minerals and phases (quartz, feldspar, calcite, microfossils). Measurements of high-field susceptibility can be made above the saturation magnetization of the ferrimagnetic minerals to determine the magnetic susceptibilities of the paramagnetic and diamagnetic minerals. The ratio of high-field and low-field susceptibilities is inversely proportional to the relative contribution of the ferrimagnetic phases to the low-field susceptibility used for AMS.

Comparison of high field susceptibility and low-field susceptibility, made by Hounslow (1990) for Leg 110 sediments and Housen et al. (1996) for Leg 156 sediments, shows that lithology controls the carriers of the AMS. Lithostratigraphic Units I and II have a highfield/low-field ratio of less than 0.10 , indicating that ferrimagnetic minerals are the dominant contributors to the low-field susceptibility in these units. Lack of a Verwey transition (Özdemir et al., 1993) and Curie temperatures of $540^{\circ}-560^{\circ} \mathrm{C}$ in most of the samples indicate that low-Ti magnetite and titanomaghemite are the primary ferrimagnetic minerals in the Unit I and II sediments (Fig. 2). The AMS measurements in these sediments will thus record low-Ti magnetite and titanomaghemite preferred orientations.

Lithostratigraphic Unit III has a high-field/low-field ratio greater than 0.90 , indicating that paramagnetic and diamagnetic minerals are the largest contributors to the low-field susceptibility. Because clay minerals have both high susceptibilities and high single-mineral anisotropies, and diamagnetic minerals and phases have low susceptibilities (Borradaile et al., 1987) and weak preferred orientations in uncemented sediments, the diamagnetic material in the sediments can be viewed as an isotropic dilutant to the measured AMS. The AMS results from Unit III will therefore provide a record of clay mineral orientations.

\section{Magnetic Susceptibility and its Anisotropy}

Magnetic susceptibility in marine sediments is often sensitive to lithological variations, or to small changes in Fe-minerals, and is commonly used in stratigraphic correlation. For this study, mean susceptibilities will be used to attempt such correlations between sites, and to assess possible changes in susceptibility carriers, particularly within zones of active fluid flow.

AMS depicts the orientation and degree of alignment (intensity) of mineral preferred orientations as an ellipsoid. The orientations of the principal susceptibility axes $\left(\mathrm{k}_{\max }>\mathrm{k}_{\mathrm{int}}>\mathrm{k}_{\min }\right)$ are commonly coaxial with the axes of the strain ellipsoid; in particular, the orientation of $\mathrm{k}_{\min }$ is almost always parallel to the orientation of the axis of the maximum shortening strain (Borradaile, 1991). Unlithified sediments in accretionary prisms can easily respond to applied stresses by development of mineral preferred orientation fabrics, so the pole to planar fabric elements (in this case $\mathrm{k}_{\min }$ ) serves as a proxy for the orientation of the maximum shortening strain (Byrne et al., 1993; Owens, 1993; Karig and Morgan, 1994).

Changes in the degree of preferred orientation (fabric intensity) will be manifested by changes in the degree of anisotropy ( $\mathrm{P}=\mathrm{k}_{\max }$ / $\left.\mathrm{k}_{\min }\right)$. The degree of anisotropy measured by AMS is a function of both mineralogy (different minerals have variable single-crystal anisotropies) and degree of alignment. This means that the fabric intensities measured by AMS for lithostratigraphic Unit II and lithostratigraphic Unit III are not directly comparable. Trends in fabric intensity are, however, directly comparable within each lithostratigraphic unit.

\section{Site 672}

Mean susceptibilities for Site 672 are highly variable. To better assess trends in the meso-scale variations of susceptibility and magnetic anisotropy, all of the data have been smoothed using a $5-\mathrm{m}$ moving average. The unsmoothed data are shown for reference in Figure 3, and the smoothed data are shown in Figure 4 and discussed below. Mean susceptibilities for lithostratigraphic Unit I are variable, with two peaks at 15 and 85 mbsf (Fig. 4A). Lithostratigraphic Unit II has, on average, higher susceptibility in the upper portion (123-180 mbsf), with a gradual decrease in susceptibility as the Unit II/Unit III boundary (227 mbsf) is approached (Fig. 4A). Note the small peak in susceptibility at 205 mbsf (labeled "A" in Fig. 4A). Lithostratigraphic Unit III has very low susceptibilities. The gradual increase in susceptibility of the Barbados sediments appears to be a characteristic of the change in sediment composition that defines the change from lithostratigraphic Unit III to Unit II. This increase is observed at all
A.

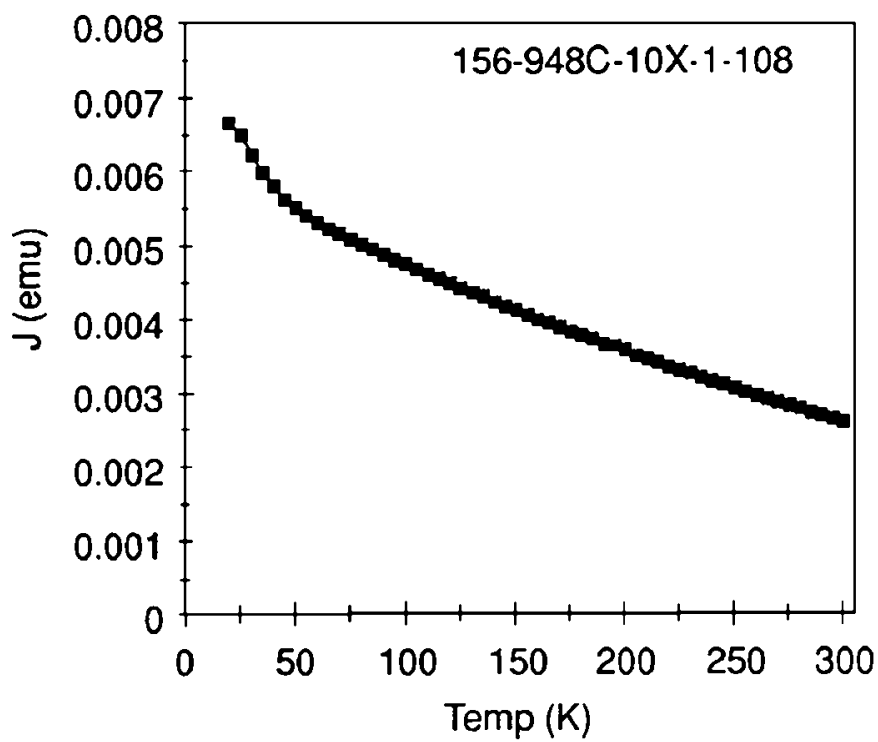

B.

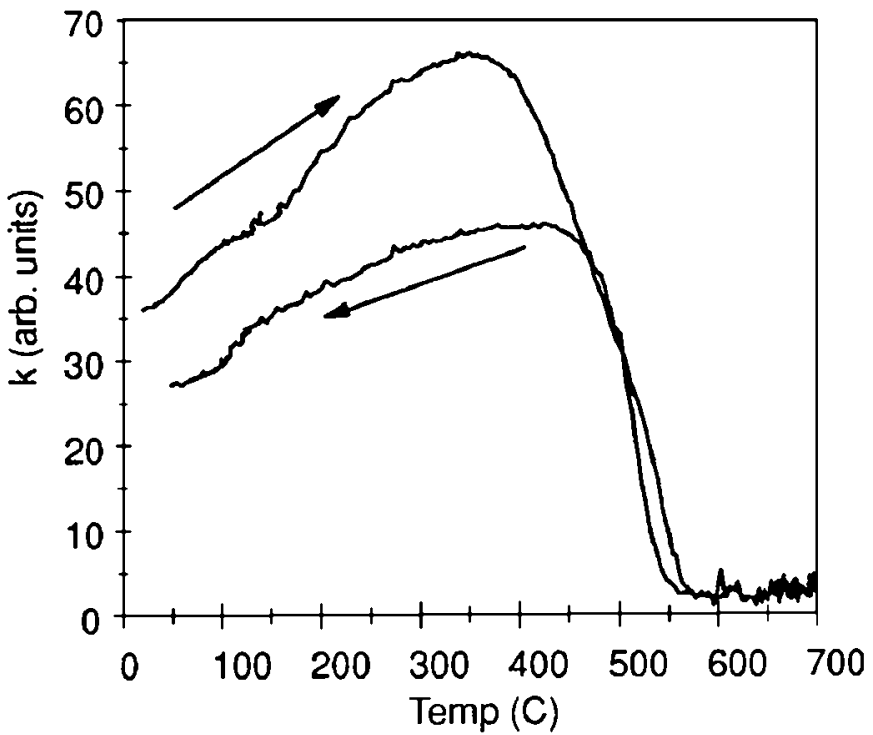

Figure 2. Rock magnetic properties of typical lithostratigraphic Unit II sediments. A. Low-temperature remanence, showing neither Verwey transition, nor indication of abundant superparamagnetic grains. B. Curie temperature, run in Argon gas, showing a Curie temperature of $560 \mathrm{C}$. 

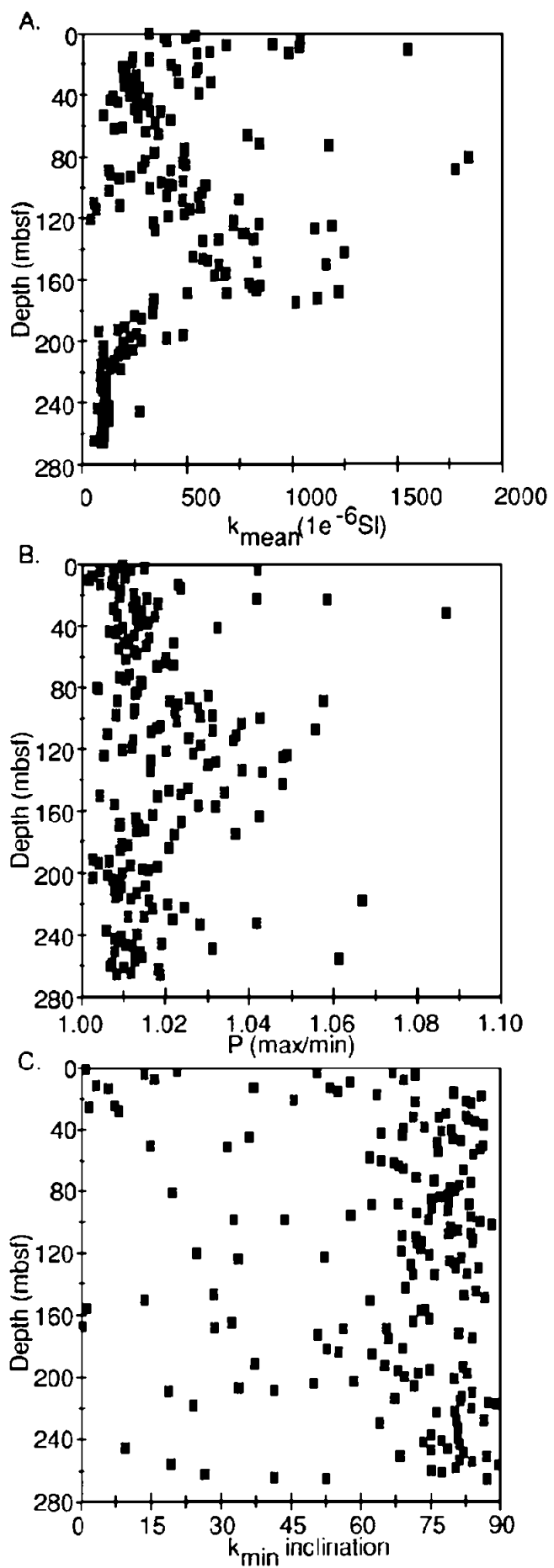

Figure 3. Magnetic susceptibility and AMS data for Site 672. ( A) Susceptibility, (B) degree of anisotropy, ( C) inclination of the minimum susceptibility axes.

of the sites recovered by Legs 78A, 110, and 156 that contain this boundary, and is also observed in the intensity of natural remanence as well as susceptibility (Hounslow, 1990, Shipley, Ogawa, Blum, et al., 1995), which indicates this increase is primarily related to an increase in the abundance of Fe-oxide minerals ([Ti]magnetite and/or [Ti]maghemite).

Magnetic fabrics at Site 672 are generally weak, with degrees of anisotropy $\left(\mathrm{P}=\mathrm{k}_{\max } / \mathrm{k}_{\min }\right)$ less than 1.04. The degree of anisotropy can
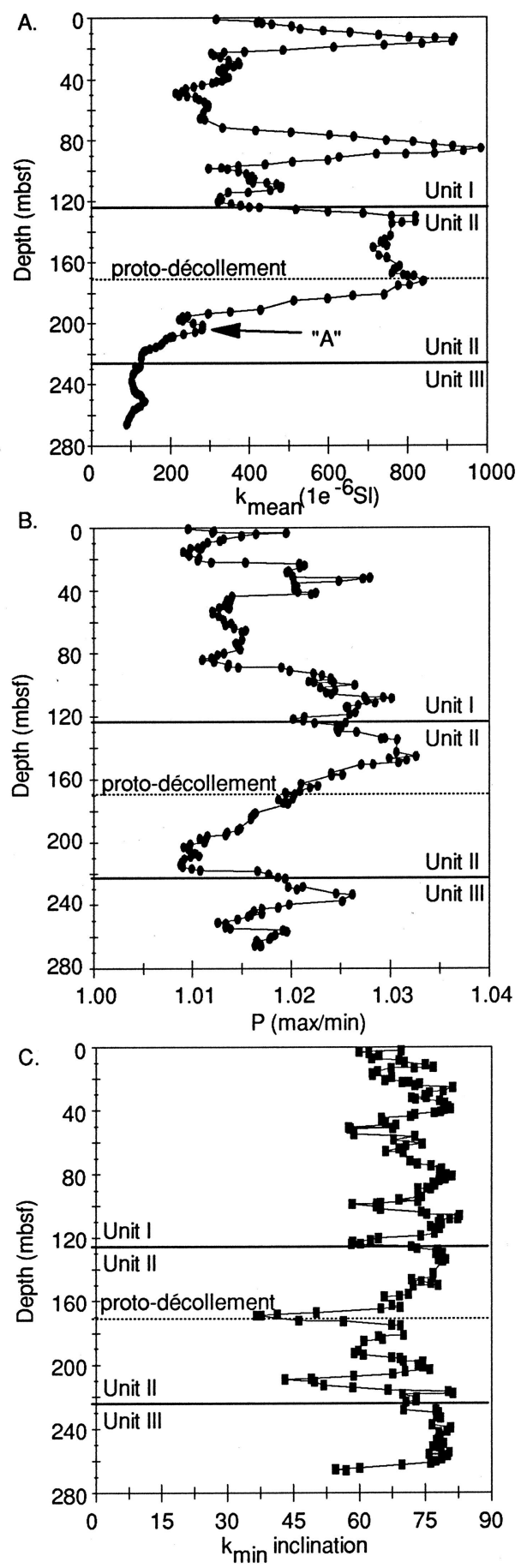

Figure 4. Magnetic susceptibility and AMS data for Site 672, smoothed with a 5-m moving average. ( A) Susceptibility, ( B) degree of anisotropy, ( C) inclination of the minimum susceptibility axes. Lithostratigraphic Units and the proto-décollement zone are also shown.

be used as a proxy of compaction in undeformed sediments, and is also used to assess the initial fabrics present in these reference site sediments. The values of $\mathrm{P}$ increase in anisotropy downhole in Unit I, decrease with depth in Unit II, and increase again with depth in Unit III (Fig. 4B). The decrease in degree of anisotropy with depth in Unit II is opposite the trend one would expect in a normally compacting sediment. The orientations of the magnetic fabrics agree with the observed structures at Site 672 . The inclination of $k \quad{ }_{\min }$ will be perpen- 
dicular to the orientation of the dominant planar fabric in these sediments (in this case, bedding), so the expected inclinations of $\mathrm{k}_{\min }$ should range from $70^{\circ}$ to $90^{\circ}$ at Site 672 . Many of the samples from Units I and II exhibited inverse magnetic fabrics, with the maximum susceptibility perpendicular to bedding (Fig. 3C), which can be caused by elongated single-domain ferrimagnetic minerals or siderite (Rochette, 1988). For these samples, the steep $\mathrm{k}_{\max }$ orientations were used as the sample's inclination in Figure 4C. The observed inclinations vary from $60^{\circ}$ to $80^{\circ}$ in most of the Site 672 sediments (Fig. 4C). Shallow inclinations occur at about $170 \mathrm{mbsf}$ and $210 \mathrm{mbsf}$. The shallow-inclination results from samples near 170 mbsf closely resemble the fabrics observed for prism sediments at Site 948 (Housen et al., 1996), with $\mathrm{k}_{\min }$ and $\mathrm{k}_{\max }$, which are subhorizontal.

\section{Site 948}

Mean susceptibilities for Site 948 samples are high $\left(>1000 \times 10^{-6}\right.$ SI) in Unit II sediments, and low in Unit III sediments. Again, to illuminate trends in meso-scale variation, the Site 948 data have been smoothed using a 5-m moving average, and the unsmoothed data are provided in Figure 5, and the smoothed data are shown in Figure 6. Prominent peaks in smoothed susceptibility occur at $435 \mathrm{mbsf}$ (near a fault), and at 485 mbsf (near the top of the décollement; Fig. 6A). These peaks in susceptibility are much higher than susceptibilities observed in any of the Unit II sediments at Site 672, and thus indicate an enrichment of Fe-oxides in the Site 948 prism sediments. Fe-oxide neomineralization is consistent with the conclusion that the Barbados prism sediments at Sites 671 and 948 are remagnetized, reached by Hounslow (1990) and Shipley, Ogawa, Blum, et al. (1995). From $\sim 500$ to 540 mbsf, the susceptibility appears to correlate well with Site 672 sediments. Note the small peak in susceptibility at $503 \mathrm{mbsf}$ (labeled "B" in Fig. 6A) within Unit II.

The degree of anisotropy for lithostratigraphic Unit II decreases from $\mathrm{P}=1.05$ in the accretionary prism to values of $\mathrm{P}<1.02$ within the décollement (Fig. 6B). The degree of preferred orientation thus generally decreases toward, and reaches a minimum in, the décollement zone. For lithologic Unit III, relatively high degrees of anisotropy occur in the underthrust sediments just below the décollement (530-540 mbsf) and relatively uniform anisotropies below $540 \mathrm{mbsf}$ (Fig. 6B).

The AMS results from Site 948 can be described in terms of two end-member orientations: one with shallowly inclined $\mathrm{k}_{\min }$ and $\mathrm{k}_{\max }$ axes, the other with subvertical $\mathrm{k}_{\min }$ and subhorizontal $\mathrm{k}_{\max }$ axes. The shallow $\mathrm{k}_{\min }$ orientations are in the accretionary prism, from 420 to about 490 mbsf (Fig. 6C). The steep $\mathrm{k}_{\min }$ orientations occur in the décollement zone and in the underthrust sediments, from 490 to 590 mbsf (Fig. 6C).

The shallow $\mathrm{k}_{\min }$ orientations define planar fabrics with steep $\left(>60^{\circ}\right)$ dips in the accretionary prism. The orientations of bedding and scaly-fabric planes in this part of the accretionary prism, with few exceptions, have shallow $\left(<60^{\circ}\right)$ dips (Shipley, Ogawa, Blum, et al., 1995). The AMS results from the accretionary prism are thus interesting in that they do not seem to correspond to the orientations of any observed macrostructures. To better understand these fabric orientations, it is desirable to compare the AMS orientations with the orientations of the tectonic elements of the Barbados accretionary prism. Although the cores were collected by rotary drilling, shipboard paleomagnetic results from a subset of the samples were of high enough quality to allow for the reorientation of 68 of the samples by rotating the measured characteristic remanence direction to present-day north (Shipley, Ogawa, Blum, et al., 1995). Reorientation of the AMS axes in the prism domain (420-490 mbsf) offers a clearer picture of their significance. The reoriented $\mathrm{k}_{\min }$ axes are mostly subhorizontal and east-west trending, matching the convergence direction of $\mathrm{N} 78^{\circ} \mathrm{E}$ (Deng and Sykes, 1995); the reoriented $\mathrm{k}_{\max }$ axes have north-south declinations and are subhorizontal (Fig. 7A). The trend of the trench in this area is nearly north-south, which is
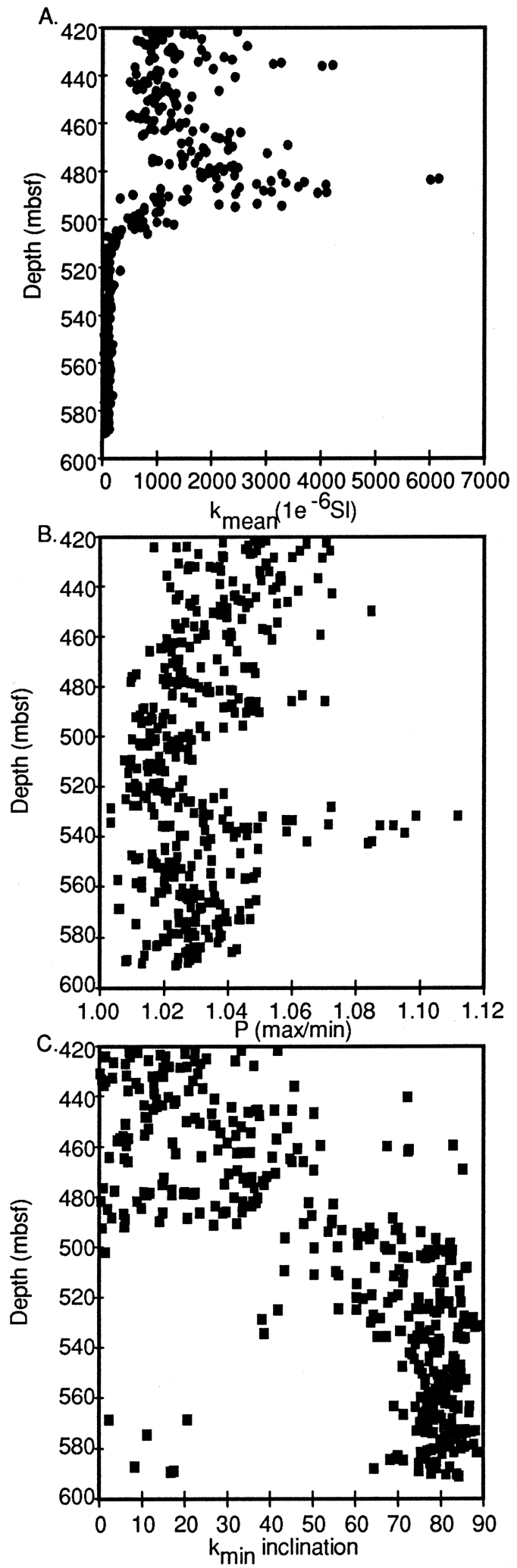

Figure 5. Magnetic susceptibilityand AMS data for Site 948, (A) Susceptibility, (B) degree if anistropy, (C) inclination of the minimum susceptibility axes. 
A.

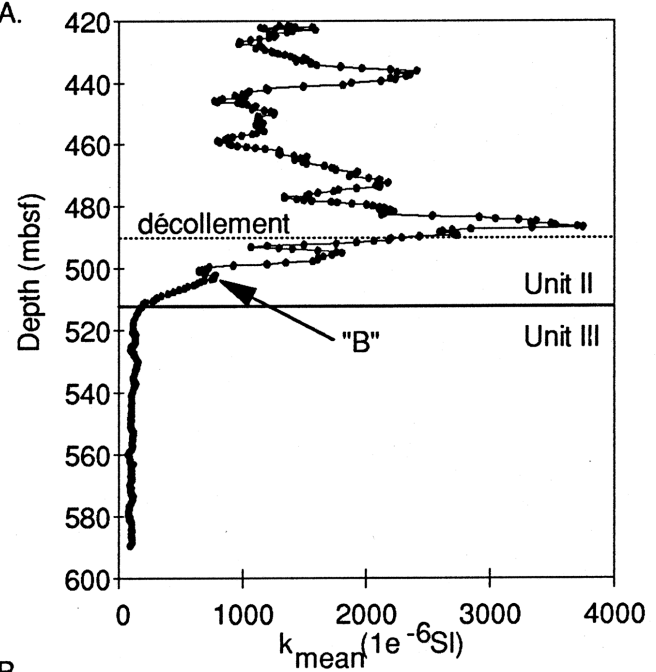

B.

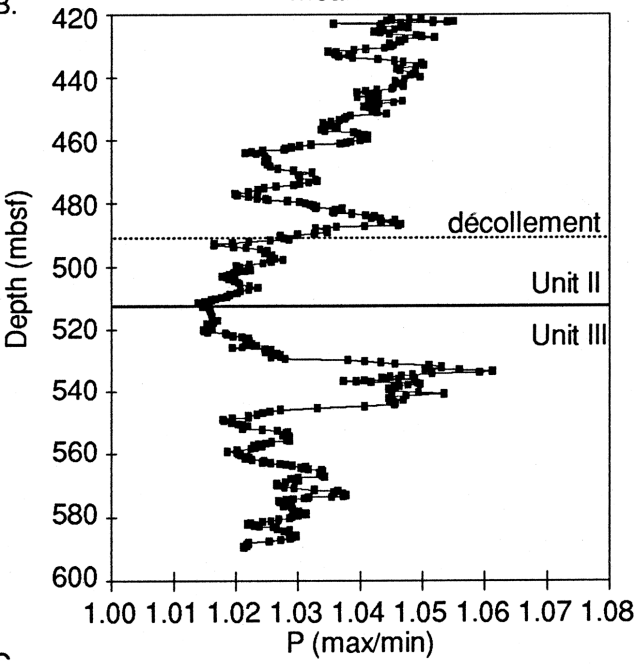

C.

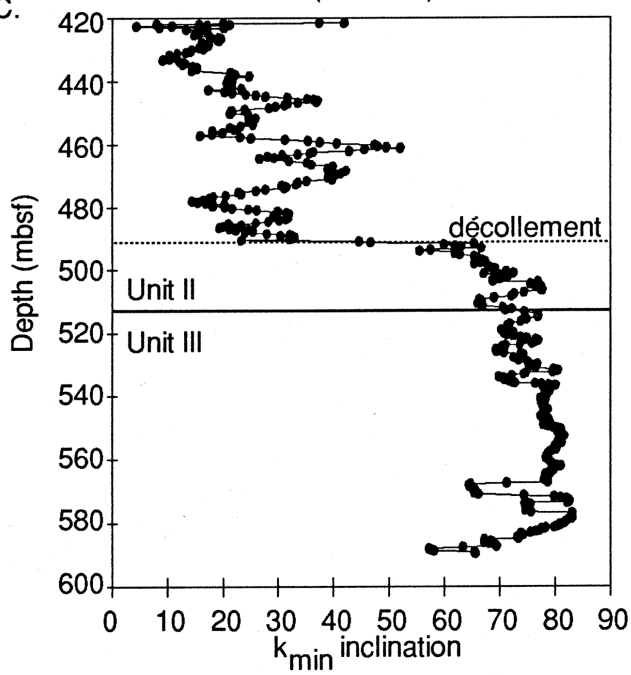

Figure 6. Magnetic susceptibility and AMS data for Site 948, smoothed with a 5-m moving average. (A) Susceptibility, (B) degree of anisotropy, (C) inclination of the minimum susceptibility axes. Lithostratigraphic units and the top of the décollement zone are also shown.

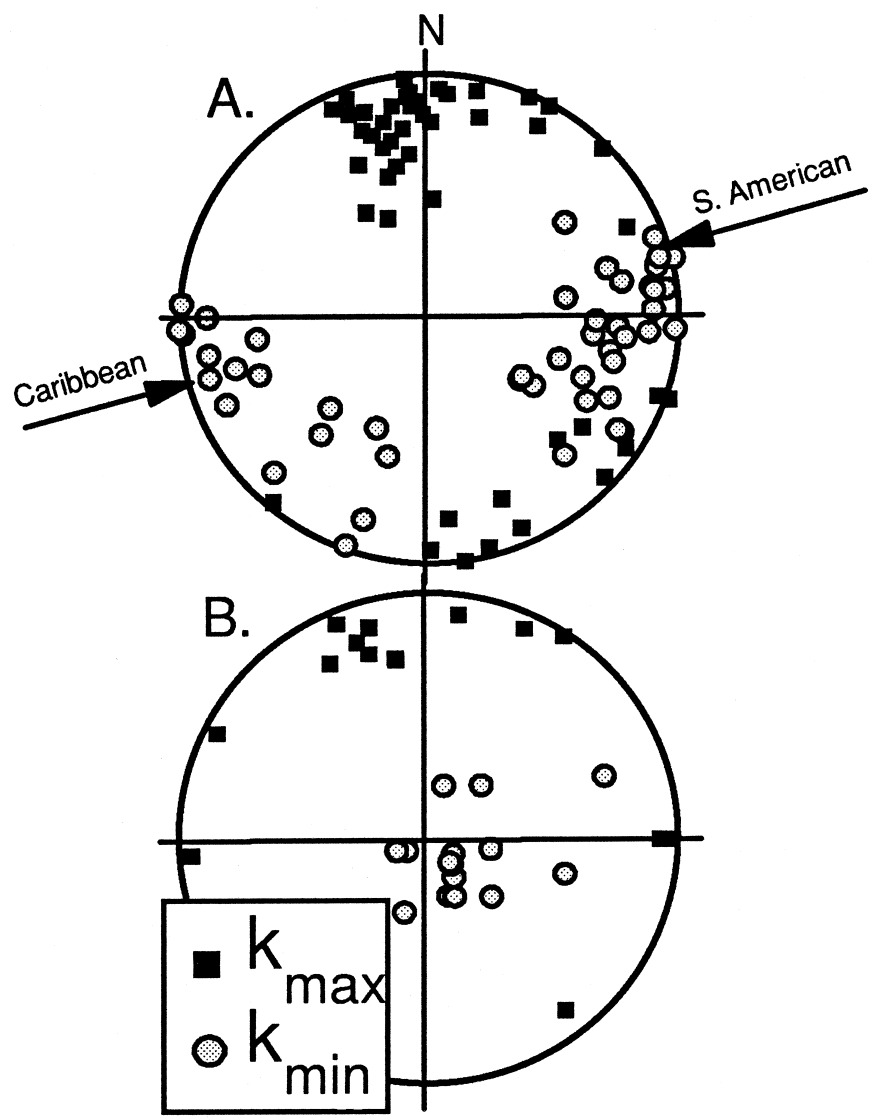

Figure 7. Equal-area, lower-hemisphere projections of reoriented AMS maximum and minimum axes for (A) the accretionary prism (420-490 mbsf), and (B) the décollement zone (490-527 mbsf) from Site 948. Arrows indicate plate convergence vector (Deng and Sykes, 1995).

closely matched by the orientation of the $\mathrm{k}_{\max }$ axes in the prism. Thus, Ti-magnetite-maghemite grains in the Barbados accretionary prism have been aligned in orientations governed by present-day tectonics, recording convergence-parallel shortening strains.

In contrast to the prism, reoriented samples from the décollement have $\mathrm{k}_{\max }$ orientations that are subhorizontal and either north-south or east-west, and have $\mathrm{k}_{\min }$ axes with steep inclinations and southeastward declinations (Fig. 7B). Measurements of scaly-fabric dips in the décollement range between $10^{\circ}$ and $30^{\circ}$ (Shipley, Ogawa, Blum, et al., 1995), which also agrees with the orientations of these AMS fabrics.

The change from shallow $\mathrm{k}_{\min }$ orientations to steep $\mathrm{k}_{\min }$ orientations occurs near the top of the décollement (Fig. 6C). By analogy with the AMS results from the prism above, these Ti-magnetitemaghemite orientations indicate a change from horizontal shortening to vertical shortening at the top of the décollement zone. The change in AMS orientations coincides (stratigraphically) with several indicators of flowing, high-pressure fluids. The primary indicator of fluid flow (a large porewater $\mathrm{Cl}^{-}$anomaly) occurs at $493 \mathrm{mbsf}$ (Shipley, Ogawa, Blum, et al., 1995). Zones of brecciated sediment suggestive of high fluid pressures also occur from 490 to 496 mbsf. Core physical properties and logging-while-drilling results also indicate the presence of high fluid pressures in two narrow intervals (505 and 514 mbsf) in the upper part of the décollement (Moore et al., 1995). The abrupt change in AMS orientations from horizontal-compression geometries to vertical-compaction geometries near the top of the décollement is thus most likely a manifestation of mechanical decoupling 
of the off-scraped prism sediments from the underthrust sediments across an interval of sediments weakened by overpressuring.

\section{Site 949}

Because of poor and discontinuous recovery, the magnetic susceptibility and fabric results from Site 949 are more difficult to interpret in terms of downhole trends. The Site 949 data are presented in unsmoothed form, again caused by low recovery. The mean susceptibilities for lithostratigraphic Unit II are higher than those of Site 672, but a little lower than the susceptibilities of Unit II at Site 948 (Fig. 8A). The decrease in susceptibility from the high values of Unit II to the low susceptibilities of Unit III occurs between 370 and 420 mbsf (Fig. 8A). Degrees of anisotropy are highly variable, and generally low (Fig. 8B). The inclination of $\mathrm{k}_{\min }$ is also highly variable within the accretionary prism, with inclinations ranging from $10^{\circ}$ to $80^{\circ}$ (Fig. 8C). Steep inclinations occur below $400 \mathrm{mbsf}$, in the décollement and the underthrust sediments. The change from relatively shallow (although scattered) $\mathrm{k}_{\min }$ inclinations in the prism to steep $\mathrm{k}_{\min }$ in the décollement and underthrust sediments matches the trend observed for Site 948 sediments, and thus the décollement at Site 949 is also likely overpressured.

\section{DÉCOLLEMENT DEFORMATION}

Comparing the magnetic susceptibility and AMS results from Sites 672 and 948 can provide certain insights into the style of deformation in the Barbados décollement. Interpretation of the magnetic anisotropy results must be made in light of the remanence and mean susceptibility data, which indicates diagenesis of (Ti)magnetite and/ or (Ti)maghemite in the prism sediments. Comparing the susceptibilities for Unit II sediments at Sites 672 and 948 indicates a two- to fivefold increase in susceptibility of Site 948 sediments relative to their counterparts at Site 672 (compare Figs. 4A and 6A). The occurrence of the greatest enhancements of susceptibility near the fault at 435 mbsf, and just above the top of the décollement at 485 mbsf, suggests a link between Fe-oxide diagenesis and fluid flow at Site 948. Possible mechanisms for the increase in susceptibility observed in these sediments include (1) increase in (Ti)magnetite or (Ti)maghemite grain size from single-domain to large, multidomain size; (2) decrease in (Ti)magnetite or (Ti)maghemite grain size from single domain to very small, superparamagnetic size; or (3) increase in the concentration of (Ti)magnetite or (Ti)maghemite grains by formation of new Fe-oxide grains. Low-temperature remanence (Fig. 2) and hysteresis parameters do not suggest either a coarsening of grain size, or the presence of a significant portion of superparamagnetic material in the prism sediments, so these two possibilities can be considered to be unlikely. New growth of (Ti)magnetite or (Ti)maghemite is consistent with both the increase in susceptibility, and the observed remagnetization of the prism sediments, and so will be considered here to be the most likely possibility.

Neocrystallization of the mineralogical carrier of the magnetic fabrics has some implications for the interpretation of the Barbados prism magnetic anisotropy data. Firstly, mechanical rotation of the (Ti)magnetite or (Ti)maghemite grains cannot be invoked to explain all of the differences in fabric intensity or orientation between the Site 672 fabrics and the Site 948 fabrics. Were this not the case, the fabric tensors from Sites 672 and 948 could have been utilized to make a direct calculation of the reorientation (strain) matrix associated with tectonic deformation of the Barbados décollement (Owens, 1974; Richter, 1992). Secondly, the magnetic fabrics measured at Site 948 will reflect a combination of differential stresses (which govern the initial orientation of neocrystallized minerals [Karato and Masuda, 1989]) and any subsequent rotation of the (Ti)magnetite or (Ti)maghemite grains following their growth (and thus will record
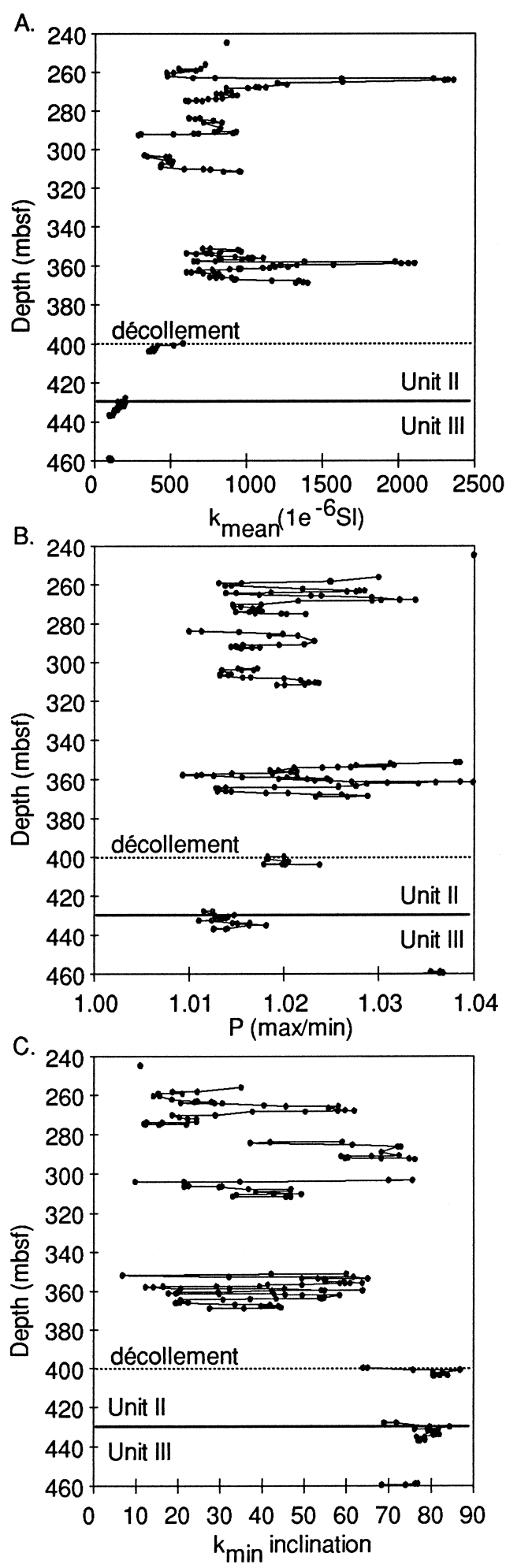

Figure 8. Magnetic susceptibility and AMS data for Site 949. (A) Susceptibility, (B) degree of anisotropy, (C) inclination of the minimum susceptibility axes. Lithostratigraphic units and the décollement zone are also shown. 
the increment of strain in the sediments following neocrystallization). It also follows that the measured fabrics will be integrating stress orientations and strain increments over the time in which neocrystallization occurs.

Interpretation of the Site 948 AMS data in this way suggests that the abrupt change from shallowly inclined, convergence-parallel $\mathrm{k}_{\min }$ orientations to nearly vertical $\mathrm{k}_{\text {min }}$ orientations between 490 and 492 mbsf reflects a change in differential stress orientations (with some component of rotation caused by post-growth strain) at the top of the Barbados décollement. As argued in Housen et al., 1996, such an abrupt change in fabric geometry can only be explained by decoupling of stresses (and strains) because of the presence of highpressure fluids. The AMS data also indicate that the decoupling horizon is very thin (approximately one or two meters at most).

The fabric orientations in sediments from the proto-décollement at Site 672 supports the interpretation that AMS records differential stress orientations as well. For the most part, the AMS results at Site 672 are consistent with a depositional/compaction fabric (Fig. 9). Samples from the proto-décollement ( $170 \mathrm{mbsf})$ differ, in that they have subhorizontal $\mathrm{k}_{\min }$ and $\mathrm{k}_{\max }$ axes; these fabrics are very similar to those found in the prism sediments at Sites 948, 949, and 671. The structures observed within the proto-décollement were interpreted to indicate initial deformation of these sediments by a "compressional bow-wave," which propagates seaward of the deformation front, and indicators of some fluid flow were found at this horizon as well (Mascle and Moore, 1990). The small peak in susceptibility, and the shallow $\mathrm{k}_{\min }$ and $\mathrm{k}_{\max }$ axes both occur at $170 \mathrm{mbsf}$, which coincides with the top of the proto-décollement at Site 672. In the absence of neocrystallization, reorientation of the steeply inclined $k_{\min }$ axes above $170 \mathrm{mbsf}$ to the shallow inclinations at $170 \mathrm{mbsf}$ would require a large shear strain, which would be manifested as a large increase in the degree of anisotropy within this interval. Such an increase is not observed, so the change in orientation is also likely caused by neocrystallization of (Ti)magnetite or (Ti)maghemite in the proto-décollement, and thus reflects the initial compression of the propagating décollement (Fig. 9).

Comparing mean susceptibilities and AMS data from the lower portion of lithostratigraphic Unit II and the upper portion of lithostratigraphic Unit III at Sites 672 and 948 may provide additional information about the extent and style of deformation in the lower portion of the décollement zone. The mean susceptibilities in sediments from 499 to 514 mbsf at Site 948 appear to correlate with the susceptibilities of sediments from 195 to 223 mbsf (compare peak " $\mathrm{B}$ " in Fig. 6A with peak "A" in Fig. 4A). This correlation likely extends into the Unit III sediments at both sites as well. Correlation of sediments within and below the décollement zone at Site 948 with their undeformed counterparts at Site 672 indicates either that the sediments in this interval at Site 948 are (largely) stratigraphically intact, or that the sediments within this interval have been deformed primarily by bedding-parallel shear. The latter explanation is consistent with the fabric geometry (steep $\mathrm{k}_{\min }$ orientations) and observations of structures such as stratal disruption in the Site 948 cores, and is in fact expected for shear zones in foliated rocks and sediments. The relatively low degrees of anisotropy within this interval would, however, suggest that ductile strains are not very large. The former possibility, although seemingly contradicted by the abundant structures observed in the Site 948 cores, is suggested not only by the susceptibility correlations, but also by shipboard paleomagnetic measurements. Mixed polarities of characteristic remanence were found from 498 to $555 \mathrm{mbsf}$; the magnetostratigraphy of the Unit III samples from below the décollement (530-555 mbsf) was assumed to be a reliable record of depositional remanence, whereas the reliability of the samples recording mixed polarities within the décollement were questioned as possibly affected by deformation (Shipley, Ogawa, Blum, et al., 1995). If this interval at Site 948 does in fact retain a primary magnetostratigraphy, which is also unaffected by the remagnetization that occurs through- out the prism sediments, this interval may well be intact. If this interpretation is valid, it implies that little displacement has occurred in sediments from 498 to 530 mbsf (i.e., most of the décollement zone defined by shipboard structural studies). The abundant structures observed in this interval may have formed as a result of deformation at high strain rates, but having low total strains, and can thus be viewed as primarily brittle, rather than ductile, structures. If this interpretation is valid, the décollement at Site 948 is a surface along which the underthrust sediments are very effectively decoupled from the overlying accretionary prism, rather than a thick $(30+\mathrm{m})$ zone of distributed shear.

The weak fabrics in the Barbados décollement are consistent with the view that brittle, rather than ductile, strains dominate the deformation behavior of these sediments (Housen et al., 1996). This conclusion is supported by other evidence concerning the deformation style of this prism. The low taper angle of the Barbados prism indicates a weak décollement (Dahlen et al., 1984), and that brittle, rather than ductile, styles of deformation will be dominant (Karig and Morgan, 1994). Studies of permeability and fault-zone fabrics (Brown et al., 1994) also emphasize the importance of brittle fractures as fluid conduits in clay-rich sediments. Failure of prism sediments by predominantly brittle modes serve to minimize the development of large ductile strains, and produce weak preferred orientations such as those measured in the Barbados prism, and in the Nankai prism (Owens, 1993).

Combined with the AMS results from Hounslow (1990) for Leg 110 , Site 671 , we can make additional inferences about the change in strain (and stress?) orientations within the prism. At Site 671, AMS results from 0 to $\sim 200$ mbsf have steep $\mathrm{k}_{\min }$ orientations (or $\mathrm{k}_{\max }$ in samples with inverse fabrics), which are consistent with bedding orientations, and suggest little or no tectonic deformation within this interval. Shortening strains within this zone are thus subvertical, and represent sediment-compaction strains (Fig. 9). From $200 \mathrm{mbsf}$ to the décollement at $490 \mathrm{mbsf}$, AMS fabrics record subhorizontal shortening roughly parallel to the plate convergence direction, and indicate that this interval is a zone of active accumulation of diffuse tectonic strains. The abrupt change in fabric orientation at $490 \mathrm{mbsf}$ marks the boundary between the offscaped prism sediments above, and the subducting sediments and oceanic crust below. Near-total strain decoupling is suggested by the return of subvertical shortening fabrics below the décollement (Fig. 9).

\section{ACKNOWLEDGMENTS}

This work was supported by a Joint Oceanographic Institutes/U.S. Science Support Program grant to Housen, and by grants from the W. M. Keck Foundation and the National Science Foundation to the Institute for Rock Magnetism (IRM). Kris Kristofferson is thanked for his help in collection of AMS and paleomagnetic data during Leg 156 , as are the members of the Leg 156 sampling parties, who sustained many scalpel wounds while collecting almost 800 oriented samples for this study. Subir Banerjee, Mike Jackson, Pete Solheid, and Harold Tobin, and referees Carl Richter and Ken Kodama are also thanked for their helpful comments on the manuscript. This is IRM contribution 9604.

\section{REFERENCES}

Agar, S.M., Prior, D.J., and Behrmann, J.H., 1989. Back-scattered electron imagery of the tectonic fabrics of some fine-grained sediments: implications for fabric nomenclature and deformation processes. Geology, 17:901-904.

Borradaile, G.J., 1991. Correlation of strain with anisotropy of magnetic susceptibility (AMS). Pure Appl. Geophys., 135:15-29.

Borradaile, G.J., Keeler, W., Alford, C., Sarvas, P., 1987. Anisotropy of magnetic susceptibility of some metamorphic minerals. Phys. Earth Planet. Inter, 48:161-166. 
Brown, K.M., Bekins, B., Clennell, M.B., Dewhurst, D.N., and Westbrook, G.K., 1994. Heterogeneous hydrofracture development and accretionary fault dynamics. Geology, 22:259-262.

Byrne, T., Brückmann, W., Owens, W., Lallemant, S., and Maltman, A., 1993. Structural synthesis: correlation of structural fabrics, velocity anisotropy, and magnetic susceptibility data. In Hill, I.A., Taira, A., Firth, J.V., et al., Proc. ODP, Sci. Results, 131: College Station, TX (Ocean Drilling Program), 365-378.

Dahlen, F.A., Suppe, J, and Davis, D., 1984. Mechanics of fold-and-thrust belts and accretionary wedges: cohesive Coulomb theory. J. Geophys. Res, 89:10087-10101.

Deng, J., and Sykes, L.R., 1995. Determination of Euler pole for contemporary relative motion of Caribbean and North American plates using slip vectors of interplate earthquakes Tectonics, 14:39-53.

Hounslow, M.W., 1990. Grain fabric measured using magnetic susceptibility anisotropy in deformed sediments of the Barbados accretionary prism: Leg 110. In Moore, J.C., Mascle, A., et al., Proc. ODP, Sci. Results, 110: College Station, TX, (Ocean Drilling Program), 257-275.

Housen, B.A., and Sato, T., 1995. Magnetic anisotropy fabrics from the Cascadia accretionary prism. In Carson, B., Westbrook, G.K., Musgrave, R.J., and Suess, E. (Eds.), Proc. ODP, Sci. Results, 146 (Pt. 1): College Station, TX, (Ocean Drilling Program), 233-254.

Housen B.A., Tobin, H.J., Labaume, P., Leitch E.C., Maltman, A.J., Shipley, T., Ogawa, Y., Ashi, J., Blum, P., Brückmann, W., Felice, F., Fisher, A., Goldberg, D., Henry, P., Jurado, M.J., Kastner, M., Laier, T., Meyer, A., Moore, J.C., Moore, G., Peacock, S., Rabaute, A., Steiger, T., Underwood, M., Xu, Y., Yin, H., Zheng, Y., and Zwart, G., 1996. Strain decoupling across the décollement of the Barbados accretionary prism. Geology, 24: 127-130.

Karato, S., and Masuda, T., 1989. Anisotropic grain growth in quartz aggregates under stress and its implications for foliation development. Geology, 17:695-698.

Karig, D.E. and Lundberg, N., 1990. Deformation bands from the toe of the Nankai accretionary prism. J. Geophys. Res., 95:9099-9109.

Karig, D.E. and Morgan, J.K., 1994. Tectonic deformation: stress paths and strain histories. In Maltman, A.J. (Ed.), The geological deformation of sediments: London (Chapman and Hall), 167-204.
Mascle, A., and Moore, J.C., 1990. ODP Leg 110: tectonic and hydrologic synthesis. In Moore, J.C., Mascle, A., et al., Proc. ODP, Sci. Results, 110: College Station, TX (Ocean Drilling Program), 409-422.

Moore, J.C., Shipley, T.H., Goldberg, D., Ogawa, Y., Filice, F., Fisher, A., Jurado, M.-J., Moore, G.F., Rabaute, A., Yin, H., Zwart, G., Brückmann, W., Henry, P., Ashi, J., Blum, P., Meyer, A., Housen, B., Kastner, M., Labaume, P., Laier, T., Leitch, E.C., Maltman, A.J., Peacock, S., Steiger, T.H., Tobin, H.J., Underwood, M.B., Xu, Y., Zheng, Y., 1995. Abnormal fluid pressures and fault-zone dilation in the Barbados accretionary prism: Evidence from logging while drilling. Geology, 23:605 608.

Morgan, J.K, and Karig, D.E., 1993. Ductile strains in clay-rich sediments from Hole $808 \mathrm{C}$ : preliminary results using X-ray pole figure goniometry. In Hill, I.A., Taira, A., Firth, J.V., et al., Proc. ODP, Sci. Results, 131: College Station, TX (Ocean Drilling Program), 141-155.

Owens, W.H., 1974. Mathematical model studies on factors affecting the magnetic anisotropy of deformed rocks. Tectonophysics, 16:249-261.

, 1993. Magnetic fabric studies of samples from Hole 808C, Nankai Trough. In Hill, I.A., Taira, A., Firth, J.V., et al., Proc. ODP, Sci. Results, 131: College Station, TX, (Ocean Drilling Program), 301-310.

Özdemir, Ö., Dunlop, D.J., and Moskowitz, B.M., 1993. The effect of oxidation on the Verwey transition in magnetite. Geophys. Res. Lett., 20:16711674.

Richter, C., 1992. Particle motion and the modelling of strain response in magnetic fabrics. Geophys. J. Int., 110:451-464.

Rochette, P., 1988. Inverse magnetic fabric in carbonate-bearing rocks. Earth Planet. Sci. Lett., 90:229-237.

Shipley, T.H., Ogawa, J., Blum, P., et al., 1995. Proc. ODP, Init. Repts., 156: College Station, TX (Ocean Drilling Program).

Date of initial receipt: 5 February 1996

Date of acceptance: 20 June 1996

Ms 156SR-010

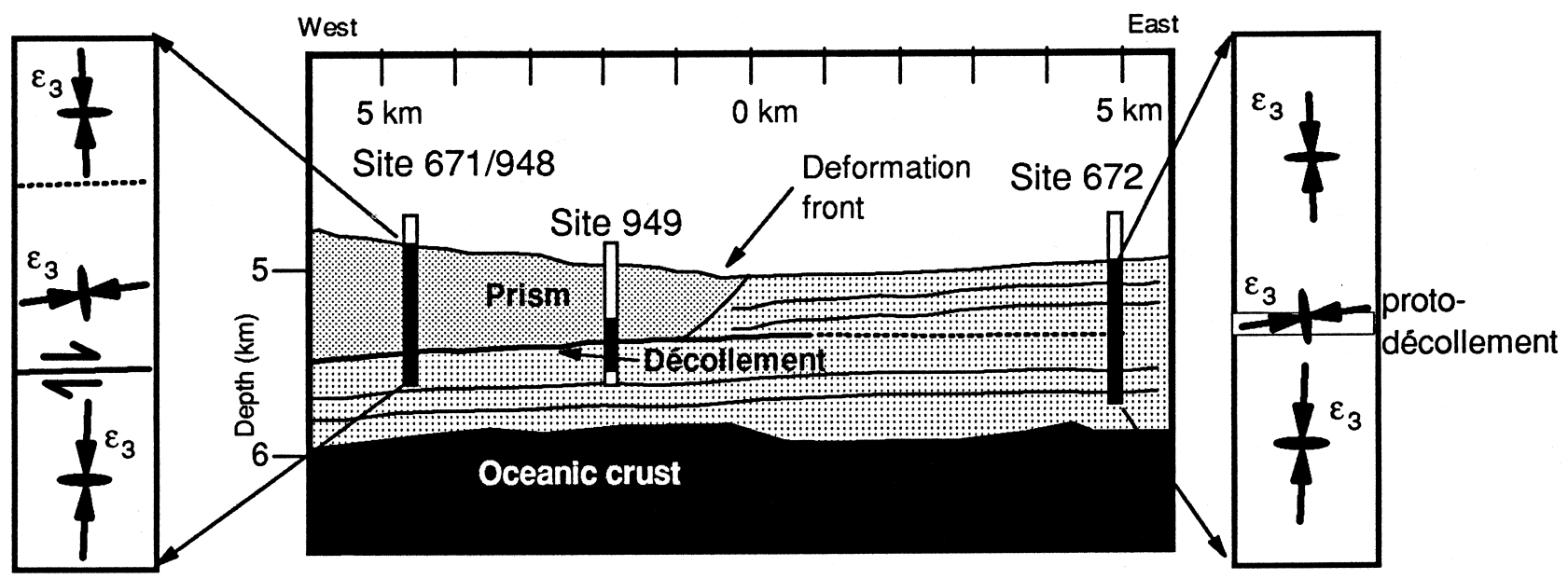

Figure 9. Summary of AMS results from Sites 671, 672, and 948, showing orientations of shortening strains within the Barbados p rism and at the reference site. 